\title{
PENGUATAN KADER KESEHATAN MELALUI EDUKASI GIZI DALAM MENGATASI ANEMIA PADA IBU HAMIL
}

\section{PENDAHULUAN}

Anemia pada ibu hamil sangat berpengaruh terhadap kualitas manusia yang akan dilahirkan dan kualitas sumber daya manusia (SDM) generasi yang akan datang. Selain itu, anemia pada ibu hamil dapat meningkatkan kejadian abortus, prematus, berat badan lahir rendah (BBLR), serta dapat menyebabkan kematian pada ibu hamil pada waktu dan sesudah melahirkan. Wanita hamil sangat sulit untuk mendapatkan cukup zat besi walaupun telah mengkonsumsi makanan yang tinggi zat besi setiap hari (Klein dan Thomson, 2008). Hal tersebut disebabkan karena zat besi adalah salah satu nutrient yang tidak dapat diperoleh dalam jumlah adekuat dari makanan yang dikonsumsi selama hamil (Bobak, dkk, 2005) dalam Nurhayati dkk (2014).

Anemia merupakan masalah yang dialami oleh $41,8 \%$ ibu hamil di dunia. Sekitar setengah dari kejadian anemia disebabkan karena defisiensi besi. Adapun prevalensi anemia pada ibu hamil di dunia yaitu diperkirakan Afrika sebesar 57,1\%, Asia 48,2\%, Eropa 25,1\%, dan Amerika 24,1\% (WHO 2015).

Prevalensi anemia pada ibu hamil di indonesia menurut Riset Kesehatan Dasar (Riskesdas) tahun 2013 sekitar 37,1\% yaitu ibu hamil dengan kadar Hb kurang dari 11,0 gram/dl, dengan proporsi yang hampir sama antara di kawasan perkotaan $(36,4 \%)$ dan perdesaan (37,8\%) Infondatin Gizi (2015).

Data Dinas Kesehatan provinsi Sulawesi Selatan menunjukkan bahwa terdapat ibu hamil dengar kadar hemoglobin 8-11 mg/dl sebesar 98,49\% dan ibu hamil dengan kadar hemoglobin $<8 \mathrm{mg} / \mathrm{dl}$ sebesar 1,15\% (Data Binkesmas, Dinas Kesehatan Provinsi Sulawesi Selatan, 2015). Di kota Makassar terdapat 46 puskesmas menurut data dari dinas kesehatan provinsi sulsel tahun 2016 pemberian kablet Fe1 (30 kablet) 100\% dan fe(90 kablet) 95,8\%. Ini menunjukkan bahwa pemerintah Sulawesi Selatan telah melakukan upaya untuk mengurangi prevalensi anemia ibu hamil. Namun sampai sekarang permasalahan anemia ibu hamil belum sepenuhnya dapat teratasi (Dinas Kesehatan Kota Makassar, 2015). 
Kurangnya pemahaman masyarakat terhadap penyakit anemia pada ibu hamil menjadi satu permasalahan dalam pemberian dukungan terhadap klien anemia pada ibu hamil. Hasil wawancara awal dengan beberapa kader kesehatan, meskipun sudah dilakukan penyuluhan tentang anemia pada ibu hamil belum sepenuhnya tersosialisasikan baik kepada kader kesehatan maupun masyarakat. Oleh karena itu perlu adanya sosialisasi untuk peningkatan pengetahuan dan pemahaman masyarakat tentang anemia pada ibu hamil agar kesadaran tentang bahaya anemia pada ibu hamil dapat menjadi motivasi dalam melakukan skrining atau deteksi dini terjadinya anemia dengan melakukan pemeriksaan kadar $\mathrm{Hb}$ dan meningkatkan upaya untuk pencegahan dan penanganan anemia pada ibu hamil di masyarakat. Upaya pemberdayaan masyarakat merupakan salah satu upaya yang dapat digunakan sebagai strategi promosi kesehatan baik dalam level primer, sekunder maupun tersier sesuai dengan piagam ottawa carter (Kemenkes, 2017).

\section{PENGARUH GIZI TERHADAP KEJADIAN ANEMIA PADA IBU HAMIL}

Status gizi ibu sebelum hamil mempunyai pengaruh yang bermakna terhadap kejadian Berat Badan Lahir Rendah (BBLR). Ibu dengan status gizi kurang baik sebelum hamil mempunyai angka kejadian 4,27 kali untuk melahirkan bayi dengan resiko BBLR dibandingkan dengan ibu yang mempunyai status gizi baik (normal) (Triwidiyanti, Sabaruddin, Anwar, 2011).

Masalah BBLR terkait dengan kondisi kesehatan ibu saat hamil, termasuk kondisi status gizi ibu menggambarkan konsumsi energi dan protein yang tidak adekuat. Berat bayi lahir adalah cerminan dari status kesehatan dan gizi selama hamil serta pelayanan antenatal yang diterima ibu. Ibu hamil dengan anemia merupakan suatu kondisi penurunan kadar hemoglobin dan jumlah eritrosit dibawah nilai normal pada ibu hamil.

Prevalensi anemia meningkat sebesar 15-20\% dengan kehamilan yang siebabkan karena sebelum wanita mengalami kehamilan mereka telah jatuh pada keadaan anemia. Kekurangan gizi pada ibu hamil dan perhatian yang kurang merupakan predisposisi anemia ibu hamil di indonesia. Anemia akan meningkat resiko terjadi kematian ibu 3,7 kali lebih tinggi jika dibandingkan ibu yang tidak anemia (Lubiz, Z. 2003, dan Supariasa, Bakrie, Fajar, 2002). Masalah gizi yang dialami ibu hamil saat ini dalah gizi kurang seperti Kurang Energi Kronis (KEK) dan anemia gizi. Status gizi ibu hamil dapat diukur dengan Lingkar Lengan Atas (LILA) $<23,5 \mathrm{~cm}$ untuk LILA yang berisiko dan $\geq 23,5 \mathrm{~cm}$ untuk LILA tidak berisiko (Lubiz, Z.2003). 
Status gizi ibu hamil bisa diketahui dengan mengukur ukuran LILA, bila $<23,5 \mathrm{~cm}$ maka ibu hamil termasuk KEK, ini berarti ibu sudah mengalami keadaan kurang gizi dalam jangka waktu yang lama, bila ini terjadi maka kebutuhan nutrisi untuk proses tumbuh kembang janin makin terlambat, akibatnya bayi yang dilahirkan menderita BBLR (Antarini, Y. 2003). Lingkar lengan atas dan kadar Hemoglobin ibu hamil mempunyai peranan penting dalam pertumbuhan dan perkembangan janin. Konsumsi makanan yang kurang dan penyakit yang dialami ibu hamil akan berakibat buruk terhadap perkembangan atau pertumbuhan janin. Pada ibu hamil diperlukan tambahan konsumsi protein untuk pembentukan sel darah merah yang berguna untuk membantu pertumbuhan janin.

\section{PENYEBAB, EDUKASI PENCEGAHAN DAN PENANGANAN ANEMIA PADA IBU} HAMIL

Anemia adalah suatu keadaan dimana tubuh kekurangan sel darah merah (eritrosit), eritrosit sendiri mengandung hemoglobin yang mempunyai afinitas terhadap oksigen dan membawa oksigen ke seluruh tubuh (Proverawati \& Atikah, 2013). Menurut Prawiroharjo (2010) anemia merupakan suatu keadaan adanya penurunan kadar hemoglobin, hematokrin dan jumlah eritrosit dibawah normal. Pada penderita anemia, lebih sering disebut kurang darah, kadar sel darah merah (hemoglobin/Hb) dibawah nilai normal.

Penyebabnya bisa karena kurangnya zat besi, asam folat, dan vitamin B12. Tetapi yang sering terjadi adalah anemia karena kekurangan zat besi. Anemia menjadi masalah terutama pada wanita usia reproduksi karena dapat menimbulkan kelelahan, badan lemah, penurunan kemampuan atau produktifitas kerja. Menurut Simanjuntak dalam Nurjanah (2012) di Indonesia 70\% ibu hamil mengalami anemia dikarenakan jarak kehamilan dan persalinan yang terlalu dekat, pendidikan rendah dan sosial ekonomi yang rendah. Anemia pada ibu hamil erat kaitannya dengan fisiologi kehamilan dimana tubuh mengalami perubahan jumlah darah meningkat dalam tubuh 20-30\% sehingga kebutuhan zat besi dan vitamin meningkat untuk pembuatan hemoglobin $(\mathrm{Hb})$ selain itu ibu hamil juga harus berbagi darah dengan bayinya sehingga kebutuhan darah 30\% lebih banyak dibanding sebelum hamil (Noversiti, 2012).

Salah satu upaya pencegahan dan penanganan anemia pada ibu hamil diantaranya dengan meningkatkan pengetahuan dan merubah sikap menjadi positif melalui edukasi tentang kebutuhan gizi selama kehamilan, periksa kehamilan minimal 4 kali selama hamil, pemberian zat besi 90 tablet, cek Hb semester I dan III, segera memeriksakan diri jika ada 
keluhan yang tidak biasa, penyediaan makanan yang sesuai kebutuhan ibu hamil, meningkatkan pengetahuan dan perilaku ibu hamil maupun keluarga dalam memilih, mengolah dan menyajikan makanan serta meningkatkan kualitas pelayanan kesehatan dan gizi (Solehati, Sari, Lukman, \& Kosasih, 2018).

Pengaruh edukasi pencegahan dan penanganan anemia terhadap pengetahuan ibu hamil di Puskesmas Haurpanggung dapat dilihat dari hasil uji test t-paired yang dilakukan pada 37 orang responden dengan nilai rata-rata pengetahuan sebelum dilakukan edukasi 51,97 dengan standar deviasi 14,55 sedangkan sesudah edukasi rata-rata 64,03 dengan standar deviasi 10,42 dan terdapat perbedaan pengetahuan sebelum dan sesudah edukasi sebesar 8,06 dengan P-Value 0,000. Nilai rata-rata sikap responden tentang pencegahan dan penanganan anemia pada ibu hamil sebelum edukasi 50,54 dengan standar deviasi 29,72 sedangkan sesudah edukasi rata-rata sikap 69,73 dengan standar deviasi 13,64 dan terdapat perbedaan sikap sebelum dan sesudah edukasi sebesar 19,19 dengan P-Value 0,000. Dimana tujuan dari edukasi ini adalah untuk meningkatkan pengetahuan dan sikap ibu hamil tentang pencegahan dan penanganan anemia pada ibu hamil, dengan meningkatnya pengetahuan ditunjang dengan sikap yang mendukung diharapkan ibu hamil akan secara sadar melakukan pencegahan dan penanganan anemia.

\section{KANDUNGAN UBI JALAR UNGU DAN ROTI RUMPUT LAUT LAWI-LAWI SUBTITUSI TEMPE SEBAGAI PERBAIKAN GIZI PADA IBU HAMIL}

Produktivitas ubi jalar di Indonesia pada tahun 2014 sebanyak 152,00 ku/ha meningkat 5,61\% pada t (Aguscik, 2019) (Syarfaini S. A., 2019)ahun 2015 sebesar 160,53 ku/ha (Badan Pusat Statistik, 2015). Tercatat pada tahun 2015 produksi ubi jalar di Provinsi Sulawesi Selatan sebesar 71.677 ton terjadi kenaikan sebesar 4.035 ton dari tahun 2014 dengan produksi sebesar 67.642 ton. Penghasil ubi jalar terbesar di Sulawesi Selatan ada di Kabupaten Bone dengan produksi sebesar 21.688 ton, disusul Kabu-paten Gowa sebesar 6.033 ton, Kabupaten Takalar 5.731 ton dan Kabupaten Maros sebesar 4.612 ton (Dinas Pertanian Sulawesi Selatan, 2015).

Ubi jalar yang di beberapa daerah disebut telo rambat atau huwi boled, merupakan sumber karbohidrat yang cukup penting dalam sistem ketahanan pangan kita. Ubi jalar ungu juga banyak dikonsumsi oleh masyarakat dengan berbagai jenis olahan. Kita mengenal ada beberapa jenis ubi jalar yaitu ubi jalar putih, ubi jalar merah dan ubi jalar ungu. Ubi jalar mengandung zat-zat yang bergizi per 100 gramnya yaitu energi 123 kkal, protein 1,8 gr, 
lemak 0,7 gr, karbohidrat 27,9 gr, kalsium $30 \mathrm{mg}$, fosfor $49 \mathrm{mg}$, besi 0,7 mg, vitamin A 7700 SI, vitamin C 22 mg, vitamin B1 0,90 mg (Winarti, 2010).

Ubi jalar (Ipomoea batatas) meru-pakan komoditas sumber karbohidrat uta-ma, setelah padi, jagung, dan ubi kayu, ser-ta mempunyai peranan penting dalam penyediaan bahan pangan, bahan baku in-dustri maupun pakan ternak. Sebagai sum-ber karbohidrat, ubi jalar memiliki peluang sebagai substitusi bahan pangan utama, se-hingga bila diterapkan mempunyai peran penting dalam upaya penganekaragaman pangan dan dapat diproses menjadi aneka ragam produk yang mampu mendorong pengembangan agro-industri dalam diversi-fikasi pangan (Zuaraida dan Supriati, 2011).

Dalam setiap 100 gr bahan yang dimakan ubi jalar mengandung betakaroten sebanyak 7700 SI. Betakaroten sering disebut dengan provitamin A yang diolah terlebih dulu oleh tubuh agar dapat menjadi vitamin A (Cahyono, 2007). Vitamin A sangat dibutuhkan oleh ibu hamil trimester kedua untuk menjaga imun, menjaga tulang, gigi, kulit dan rambut yang sehat sedangkan untuk janin adalah untuk saraf dalam otak, membentuk selaput sel dan penglihatan (West, 2010).

Kandungan gizi ubi jalar ungu varie-tas antin-3 yaitu sebanyak 150,7 mg an-tosianin, $1,1 \%$ serat, $18,2 \%$, pati, $0,4 \%$ gula reduksi, $0,6 \%$ protein, $0,70 \mathrm{mg}$ zat besi dan $20,1 \mathrm{mg}$ vitamin C (Balitbangtan, 2016).

Senyawa antioksi dan selain an-tosianin yang terdapat pada ubi jalar adalah vitamin $\mathrm{C}$, vitamin E, lutein, zeaxanthin, dan betakaroten yang merupakan pasangan antioksidan karotenoid (Teow dkk (2007) dalam Husna dkk, 2013). Dari semua varie-tas warna umbi ubi jalar yang terdiri dari warna putih, kuning, oranye dan ungu. Hasil penelitian analisis vitamin $\mathrm{C}$ pada varietas ubi jalar yang umbinya berwarna ungu memiliki kandungan vitamin $\mathrm{C}$ paling besar yaitu 0,0177 mg/100 gram (Nathania dkk, 2013).

Ubi ungu mengandung pigmen antosianin yang lebih tinggi daripada varietas lain. Warna ungu yang kuat menunjukkan tingginya kadar antioksidan dan antosianin didalamnya. Kandungan protein di dalam ubi jalar ungu lebih tinggi daripada ubi jalar kuning 0,77\% (Winarti, 2010). Kandungan betakaroten dan vitamin C bermanfaat sebagai antioksidan pencegah kanker dan beragam penyakit kardiovaskuler. Kandungan serat dan pektin di dalam ubi jalar sangat baik untuk mencegah ganguan pencernaan seperti wasir, sembelit hingga kanker kolon (Sutomo, 2007).

Sedangkan produksi rumput laut nasional pada jenis lawi-lawi (ceulerpa $s p$ ) dalam kurun 2011-2015 menunjukkan kenaikan dengan rata-rata pertumbuhan 22,2 \%. Pada 2015, 
volume produksi rumput laut nasional seki-tar 11,2 juta ton dengan nilai Rp 13,2 tril-iun atau naik 9,8\% dari volume produksi tahun sebelumnya sebanyak 10,2 juta ton (Kementrian Kelautan dan Perikanan, 2016). Rumput laut lawi-lawi memiliki kandungan gizi yang cukup tinggi sebagai sumber protein nabati maupun mineral. Jenis rumput laut ini, mengandung protein $17-27 \%$, lemak $0,08-1,9 \%$, karbohidrat $39-50 \%$, serat 1,3 -12,4\%, dan kadar abu 8,15-16,9\% serta kadar air yang tinggi $80-90 \%$ (Verlaque et al, 2003 dalam Burha-nuddin, 2014: 8).

Untuk menambah kandungan gizi produk olahan berbahan dasar rumput laut lawilawi, dibutuhkan penambahan pangan lokal lain yang dapat dioptimalkan keberadaannya dan merupakan sumber protein nabati serta kaya akan Fe dan zat gizi lainnya. Sebenarnya kualitas protein dari golongan nabati masih tergolong rendah dibandingkan protein hewani, namun kombinasi sumber nabati yang bervariasi mampu memberikan efek komplementari asam amino essensial (Winarno, 2002 dalam Estiningtyas, 2014: 9). Tempe merupakan salah satu bahan makanan yang tepat. Setiap 100 gram tempe mengandung protein 20,8 gram, lemak 8,8 gram, serat 1,4 gram, kalsium $155 \mathrm{mg}$, fosfor $326 \mathrm{mg}$, zat besi $4 \mathrm{mg}$, vitamin B1 0,19 mg,dan karoten $34 \mu \mathrm{g}$ (Bastian, dkk, 2013: 5).

Salah satu jenis produk makanan yang saat ini sering dikonsumsi di masyarakat mulai dari anak-anak hingga dewasa adalah roti. Menurut Mudjajanto dan Yulianti (2004) dalam Suryatna (2015), roti merupakan produk olahan makanan yang terbuat dari tepung terigu yang difermentasi dengan ragi dan ditambahkan bahan pengembang lainnya serta memiliki aroma atau citarasa yang disukai konsumen kemudian dilakukan pemanggangan.

\section{POLA MAKAN PADA WANITA USIA SUBUR}

Wanita pada usia subur, termasuk remaja perempuan adalah salah satu kelompok berisiko tinggi untuk anemia. Penurunan kadar hemoglobin lazim ditemukan pada remaja putri karena siklus menstruasi. Sebuah penelitian di india memperlihatkan bahwa lebih dari $60 \%$ wanita di usia remaja mengalami anemia.

Wanita usia subur (WUS) merupakan wanita yang terdapat pada rentang umur dimana pada usia tersebut organ reproduksi wanita mulai matang dan sudah berfungsi dengan baik dengan rentang usia 15-49 ta-hun termasuk wanita hamil, wanita tidak hamil, ibu nifas, calon pengantin, remaja putri, dan pekerja wanita. Kekurangan ener-gi kronik yang sering menyerang pada wanita usia subur menggambarkan asupan energi dan protein yang tidak adekuat. Salah satu indikator untuk mendeteksi risiko KEK dan status gizi pada WUS dengan melakukakan pengukuran antropometri yai-tu pengukuran Lingkar Lengan bagian Atas 
(LILA) pada lengan tangan yang tidak ser-ing melakukan aktifitas gerakan yang berat. Nilai ambang batas yang digunakan di Indo-nesia adalah nilai rerata LiLA $<23,5 \mathrm{~cm}$ yang meggambarkan terdapat resiko keku-rangan energi kronik pada kelompok umur wanita usia subur (Angraini, 2018).

Pola konsumsi individu merupakan salah satu faktor penyebab langsung ter-hadap keadaan status gizi dan status kesehatan pada wanita usia subur. Pola konsumsi yang tidak adekuat dapat men-imbulkan suatu gangguan kesehatan pada seseorang. Jika jumlah pola konsumsi ma-kanan selama satu hari tidak sesuai dengan pola gizi seimbang dan tidak sesuai dengan kebutuhan gizi individu, maka pola kon-sumsi tersebut terukur dalam kategori kurang baik. Gizi seimbang merupakan suatu susunan makanan sehari-hari yang mengan-dung zat-zat gizi dalam jenis dan jumlah yang sesuai dengan kebutuhan tubuh dan terpenuhi, dengan memerhatikan prinsip variasi makanan atau keanekaragaman, kebersihan, aktivitas fisik, dan berat badan ideal (Supariasa et al., 2002).

Pola makan yang tidak seimbang dan tidak sesuai dengan kebutuhan gizi individu menyebabkan terjadinya ketidakseimbangan asupat zat gizi yang masuk kedalam tubuh sehingga kekurangan gizi dapat terjadi pada wanita usia subur dimasa kehamilannya.

Kerurangan energi kronik yang terjadi pada wanita unsia subur merupakan akibat dari faktor tidak langsug seperti lingkungan dan faktor langsun dari individu manusia yang didukung oleh konsumsi zat gizi sesuai kebutuhan, maka zat gizi yang ter-simpan dalam tubuh digunakan untuk me-menuhi kebutuhan. Apabila keadaan terse-but terus berlangsung dalam jangka waktu lama, maka simpanan zat gizi digunakan sebagai sumber energi dan akan habis, yang pada akhirnya terjadi kemerosotan jaringan dalam tubuh.

WUS dengan pola makan kategori kurang dapat diindikasikan bahwa WUS tersebut tidak tercukupi kebutuhan nutrisinya sesuua angka kebutuhan gizi yang direkomendasikan sehingga berpotensi terjadinya ganggunng gizi atau kekurangan gizi. Kebiasaan pola makan yang kurang memenuhi standar, jika berlangsung lama maka WUS akan berisiko mengalami KEK dibandingkan mereka dengan pola makan yang baik, meskipun pada saat penelitian keadaan Wanita Usia Subur (WUS) dikate-gorikan tidak mengalami KEK.

Herbold \& Edelstein (2012) mengemukakan bahwa faktor yang berhub-ungan dengan pola makan salah satunya adalah tingkat pengetahuan seseorang. Tingkat pengetahuan pada WUS sangat mempengaruhi terhadap pola konsumsi da-lam kehidupannya. WUS yang mengetahui dan paham mengenai pentingnya nutrisi bagi kebutuhan tubuhnya, maka WUS ter-sebut memilik kesadaran yang tinggi ten-tang pentingnya berpola makan yang baik. 
Keadaan gizi Wanita Usia Subur (WUS) bisa dipengaruhi oleh ketidakseimbangan asupan jenis dan variasi makanan yang dikonsumsi, kandungan zat gizi, porsi ma-kanan dan frekuensinya, tingkat ke-percayaan dan penerimaan terhadap ma-kanan misalnya : pantangan makan dan rasa suka atau tidak suka terhadap suatu ma-kanan.

\section{HUBUNGAN TINGKAT PENGETAHUAN IBU HAMIL TENTANG ANEMIA DENGAN KEJADIAN ANEMIA PADA IBU HAMIL TRIMESTER III}

Masyarakat mempunyai peranan terutama dalam pemantauan wilayah setempat ibu dan anak (PWS-KIA), dimana salah satu indikatornya adalah peningkatan deteksi dini resiko tinggi/komplikasi kebidanan oleh masyarakat. Upaya lain dalam partisipasi masyarakat yaitu meningkatkan "gerakan sayang ibu" yang diwujudkan dengan beberapa program yang dilakukan dan dikelola oleh masyarakat seperti desa siaga (Manuaba, 2008). Desa siaga yaitu desa yang penduduknya memiliki kesiapan sumber daya dan kemampuan serta kemauan untuk mencegah serta mengatasi masalah kesehatan, bencana, kegawatdaruratan, dan kesehatan secara mandiri. (Kepmenkes, 2010)

Berdasarkan studi pendahuluan yang dilakukan pada bulan Februari 2016 dengan melihat data sekunder dari tahun 2014 tentang anemia pada ibu hamil yaitu ibu hamil yang melakukan pemeriksaan pemeriksaan $\mathrm{Hb}$ sebanyak 670 yang mengalami anemia sebanyak $248(37,01 \%)$, dan pada tahun 2015 ibu hamil yang memeriksakan Hb sebanyak 925 dan yang mengalami anemia sebanyak $346(37,40 \%)$, trimester I 1,73 \%, Trimester II 39,30\%, dan trimester III sebanyak 57,22\% ibu hamil yamg mengalami anemia.

Berdasarkan uji statistik nonparametrik menggunakan uji Kendall-Tau dengan taraf kesalahan 5\% dan tingkat kepercayaan 95\%, didapatkan nilai signifikansi sebesar 0,006. Karena nilai signifikansi $<0,05$ dengan demikian hasil tersebut menunjukkan bahwa ada hubungan antara tingkat pengetahuan tentang anemia dengan kejadian anemia pada ibu hamil. Hal ini juga menunjukkan hasil nilai koefisien korelasi yaitu Pengetahuan atau kognitif merupakan domain yang sangat penting untuk terbentuknya tindakan seseorang (ovent behavior). Dari pengalaman dan penelitian ternyata perilaku yang disadari oleh pengetahuan akan lebih bertahan lama dari pada perilaku yang tidak disadari oleh pengetahuan (Notoatmodjo, 2010). Tingkat pengetahuan salah satunya dapat diketahui melalui informasi, seseorang yang mempunyai sumber informasi yang lebih banyak akan mempunyai pengetahuan yang lebih luas. Dalam penelitian ini dari 61 responden sebanyak 25 orang (41\%) memiliki pengetahuan baik, pengetahuan seseorang biasanya diperoleh dari pengalaman yang berasal dari berbagai sumber misalnya petugas kesehatan, media masa, 
media elektronik, buku petunjuk kesehatan, media poster, kerabat dekat dan sebagainya (Manuaba, 2010) 


\section{DAFTAR PUSTAKA}

Aguscik, R. (2019). Pengaruh Status Gizi Terhadap Kejadian Anemia Pada Ibu Hamil Di Daerah Endemik Malaria Kota Bengkulu. (JPP) Jurnal Kesehatan Poltekkes Palembang, 97-100.

Alam, S., Ansyar, D. I., \& Satrianegara, M. F. (2020). Eating pattern and educational history in women of childbearing age. Al-Sihah: The Public Health Science Journal, 12(1), 81-91.

Kafiyanti, N., Muhartati, M., \& Kasjono, H. S. (2016). Hubungan Tingkat Pengetahuan Ibu Hamil Tentang Anemia Dengan Kejadian Anemia Pada Ibu Hamil Trimester III di Puskesmas Jetis Kota Yogyakarta.

Setyaningtyas, S. W., Rochmah, T. N., Mahmudiono, T., Hidayah, S., \& Adhela, Y. D. (2020). Gambaran Pengetahuan, Sikap, dan Perilaku Kader Palang Merah Remaja (PMR) di SMAN 2 Lamongan Terhadap Program Suplementasi Tablet Tambah Darah. Amerta Nutrition, 4(3), 213-217.

Sukmawati, L. M. (2019). Pengaruh Edukasi Pencegahan dan Penanganan Anemia Terhadap Pengetahuan dan Sikap Ibu Hamil. Jurnal Keperawatan BSI, 42-47.

Sukmawati, S., Mamuroh, L., \& Nurhakim, F. (2018). Pemberdayaan Masyarakat Dalam Upaya Pencegahan Dan Penanganan Anemia Pada Ibu Hamil Di Puskesmas Haurpanggung. Jurnal Pengabdian Kepada Masyarakat, 2(9), 804-807.

Suparni, F. R. (2020). Pengaruh Pemberian Ubi Jalar Ungu (Ipomoea Batatas) Terhadap Peningkatan Lingkar Lengan Atas Ibu Hamil Dengan Kekurangan Energi Kronis Di Wilayah Puskesmas Kedungwuni II Kecamatan Kedungwuni Kabupaten Pekalongan Tahun 2018. Jurnal Ilmiah Kesehatan Keperawatan, 62-67.

Syarfaini, D. S. (2019). Analisis Kandungan Zat Gizi Roti Rumput Laut Lawi-Lawi (Ceulerpa racemosa) Subtitusi Tempe Sebagai Alternatif Perbaikan Gizi Masyarakat. Al-Shihah : Public Health Science Journal, 94-106.

Syarfaini, M. F. (2017). Analisis Kandungan Zat Gizi Biskuit Ubi Jalar Ungu (Ipomoea batatas L. Poiret) Sebagai Alternatif Perbaikan Gizi Di Masyarakat. Al-Shihah : Public Health Science Journal, 138-152. 
Syarfaini, S. A. (2019). Faktor Risiko Kejadian Anemia Pada Ibu Hamil Di Wilayah Kerja Puskesmas Sudiang Raya Kota Makassar. Al-Shihah : Public Health Science Journal, 143-155. 